\title{
ALGUMAS COMPARAÇÕES ENTRE A TEOGONIA, DE HESÍODO E SATURNO DEVORANDO UM FILHO, DE FRANCISCO DE GOYA
}

\author{
Jorge Antonio Berndt \\ Universidade Estadual do Oeste do Paraná - Unioeste (Brasil) \\ jorgeberndt6@gmail.com \\ Marianna Bernartt Silva \\ Universidade Estadual do Oeste do Paraná - Unioeste (Brasil) \\ bernartt.marianna@outlook.com \\ Valdeci Batista de Melo Oliveira \\ Universidade Estadual do Oeste do Paraná - Unioeste (Brasil) \\ valzinha.mello@hotmail.com
}

Recebido: 15/08/2020 - Aprovado: 01/10/2020 - Publicado: 15/04/2021

DOI: doi.org/10.17533/udea.lyl.n79a28

\begin{abstract}
Resumo: A partir da escritura da epopeia de Hesíodo, efabulações da cena do engolimento dos filhos de Crono se tornaram recorrentes na iconografia ocidental, com numerosas releituras produzidas desde a Antiguidade clássica até o período romântico. Nesse cenário, por intermédio de uma perspectiva comparatista e semiótica, se analisa a tradução da segunda fase cósmica da Teogonia, elaborada por Francisco de Goya, em Saturno devorando um filho. Constata-se que a composição do poema se estabelece no passado épico absoluto e da pintura no inquietante. Ademais, se reconhece a transversalidade do processo de significação nas matrizes verbal e visual entre as obras.
\end{abstract}

Palavras chave: Saturno devorando um filho; Teogonia; grotesco; poética; tradução intersemiótica.

\section{SOME COMPARISONS BETWEEN HESIOD'S THEOGONY AND FRANCISCO DE GOYA'S SATURN DEVOURING HIS SON}

\begin{abstract}
After Hesiod's epopee, depictions of the swallowing scene of Chrono's children became frequent in the western iconography, with reinterpretations made since the classic antiquity until the romantic period. Thus, by means of a comparative and semiotic perspective, it is sought to analyze the translation of the Theogony's second cosmic phase produced by Francisco de Goya, in Saturn Devouring His Son. It is concluded that the poem's composition is stablished in the absolute/epic past, while the painting's one in the uncanny. Besides, it is identified, in the texts' relation, the transversality of the semiosis process in verbal and nonverbal expressions.
\end{abstract}

Key words: Saturn Devouring His Son; Theogony; grotesque; poetics; intersemiotic translation.

Editores 
Algumas comparações entre a Teogonia, de Hesíodo e Saturno Devorando Um Filho, de Francisco de Goya

\section{Introdução}

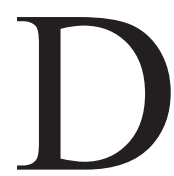

e acordo com pensadores de diferentes vertentes filosóficas e literárias, como Giambattista Vico (2015), Erich Auerbach (2015) e Marvin Carlson (1997), a poesia e o drama grego inauguraram e influenciaram os rumos da Literatura Ocidental. Ao empregar processos e modos particulares de utilização da linguagem, Homero (928 a.C. - 898 a.C.), Safo (630 a.C. - 570 a.C.) e Eurípedes (480 a.C. - 406 a.C.), por exemplo, foram responsáveis por apresentar um universo artístico inédito à imaginação e à consciência europeia. A criação literária desses escritores apresenta potencial de preservação da memória e cultura helena e potencializam as faculdades afetivo-cognitivas de seus ouvintes, hoje leitores, consagrando-os como legítimos clássicos da literatura. Isto é, como integrantes daquele seleto grupo de livros que, conforme Calvino (1993, p. 11), nunca terminaram de comunicar o que tinham para dizer ao seu leitor, mesmo depois de dois milênios.

De maneira semelhante, a Teogonia (Hesíodo, 1995) também teve um papel significativo para a constituição da tradição clássica ao representar o antiquíssimo mundo mítico do povo heleno. Segundo as observações de Torrano (Hesíodo, 1995) acerca da estrutura desse poema épico, ela se forma atendendo a um determinado número de ordens cósmicas que constituiriam a própria organização do enredo. Tais ordens corresponderiam a um conjunto heterogêneo de três séries sucessivas de manifestações divinas sobre o universo grego figurado. Elas conteriam as divinas designações das musas a respeito do ciclo lendário de criação, manutenção e destruição do universo.

O presente texto interpela uma importante fase dessa narrativa mítica para a formação da tradição iconográfica artística que é a segunda fase cósmica: o reinado de Crono, caracterizada pelos episódios da castração de Urano e a consequente ascensão de seu herdeiro ao trono dos céus, o engolimento dos deuses olimpianos e o posterior destronamento desse Titã. Esse episódio atingiu grande notoriedade, de modo que, posteriormente, vários dos seus sucessos acabaram sendo traduzidos de diferentes maneiras para diversas formas de linguagens artísticas, sejam de matriz verbal, icônica ou sonora, avançando sobre criações tanto do sistema de signos verbais quanto não-verbais em várias culturas que resultaram do mundo grego.

Nessa conjuntura, desde os períodos mais remotos foram produzidas traduções intra e intersemióticas, que, muitas vezes, procuravam seguir a proposição artística, segundo o modelo e os meios expressivos do legado grecoromano, ou fora dele. Na Antiguidade, havia o modelo solene, grave e piedoso, semelhante ao próprio poema, encontrado em vasos e afrescos. Entretanto, na Idade Média, observa-se um padrão de subversão da poética recorrente até então, como em Maître de Rohan (1410-1440). Conforme Macey (1978), a partir do Renascimento e do movimento Barroco, houve um retorno ligeiramente modificado à poética clássica, que perdurou até a convenção romântica, quando teve início um movimento de renovação estética responsável por afetar os meios tradicionais de expressão artística pelo poder transformador da nova linguagem proposta por uma nova poética em relação à representação do mito teogônico de Crono, com Francisco José de Goya y Lucientes (1746-1828).

O gravador e pintor espanhol Francisco de Goya chamou a obra Saturno, ou ainda Saturno devorando um filho, e tal trabalho foi produzido entre os anos de 1820 e 1823, nas paredes de sua casa, em Madri, em simultâneo 
Algumas comparações entre a Teogonia, de Hesíodo e Saturno Devorando Um Filho, de Francisco de Goya a um conjunto de outras treze pinturas caracterizadas pela escuridão, deformidade e estranheza. Dentre elas, a obra que se propõe estudar surge como emblema em razão de transpor a segunda fase cósmica da Teogonia para uma linguagem não-verbal, a partir do que Todorov (2014) denominou de uma perspectiva inovadora e desencadeadora da mais marcante revolução pictórica europeia.

Desse modo, com o objetivo de identificar os sentidos evocados por essa tradução considerada transformadora, se buscou analisar os métodos e procedimentos empregados por Francisco de Goya ao transpor a cena de uma obra de matriz verbal — o poema Teogonia — para uma de matriz pictórica — a pintura Saturno devorando um filho (Goya, 1820-1823) — e de que modo esses elementos interferiram na constituição formal e temática do quadro e retroativamente do próprio escrito grego. Se toma por referencial teórico-metodológico os novos estudos da Literatura Comparada, que com uma ampla área de atuação passaram a contemplar a relação entre as múltiplas variedades textuais e discursivas, como reavalia Carvalhal (1986). Destarte, se recorre à concepção do modelo triádico, de Charles Peirce (2005), e os estudos da semiótica de Lúcia Santaella (2001; 2009) e Plaza (2013). As noções artísticas tratadas por Arnheim (2005) e Todorov (2014). Também foram usadas as concepções relacionadas ao mundo épico, inquietante e grotesco em Sigmund Freud (2010), Mikhail Bakhtin (2010; 2014) e Wolfgang Kayser (1986).

Tendo em vista que o presente estudo foi planejado e desenvolvido como uma investigação semiótica, voltado para as relações travadas entre os sistemas sígnicos das obras já apontadas, o caminho escolhido constou dos seguintes passos: (1) exame da narrativa teogônica, identificando na poética seus preceitos versificatórios, enredo e desdobramento de sentidos gerados; (2) análise formal da pintura, marcas que a perfazem grotesca e a sua ressignificação da matriz verbal, sempre em articulação com debate sobre as duas matrizes de linguagem que compõem as obras em tela. As traduções de palavras e excertos do grego para o português apresentadas neste trabalho são de J. A. A. Torrano (Hesíodo, 1995). Além disso, com exceção das citações diretas, doravante, os títulos Teogonia e Saturno devorando um filho não serão acompanhados pelas referências de autor e ano a fim de se reduzir a reiteração exaustiva das mesmas informações.

\section{A constituição do engolimento na Teogonia, de Hesíodo: o universo ocluso do epos helênico}

Em concordância às anotações da tábua cronológica de Vico, exposta na Ciência nova (2015), a obra Teogonia, atribuída pelo pensador napolitano a Hesíodo (VIII a. C. - VIII a.C.), é uma antiquíssima epopeia de origem incerta escrita em um grego provavelmente pertencente ao da mesma época em que foram registrados por escrito os textos da Ilíada (Homero, 2005) e da Odisseia (Homero, 2003), reivindicados a Homero. Apesar dos conflitos, celebrações e descrições genealógicas desse poema terem inspirado numerosas releituras ao longo dos últimos dois milênios, se tratou de seu enredo e estrutura de uma maneira global, com o propósito de expor-se os principais elementos circunscritos à constituição do episódio a ser analisado. Tendo em vista essa abordagem, eis os versos iniciais do poema: 
Algumas comparações entre a Teogonia, de Hesíodo e Saturno Devorando Um Filho, de Francisco de Goya

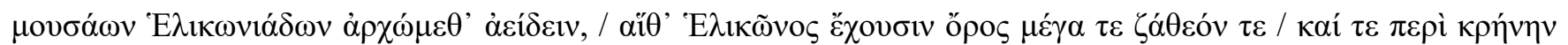

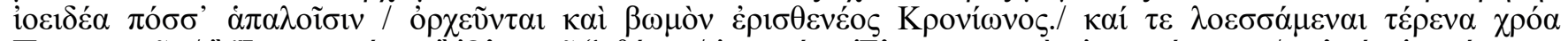

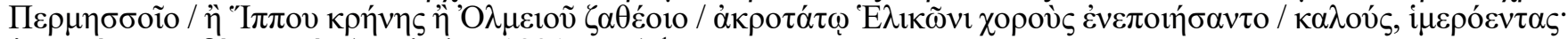

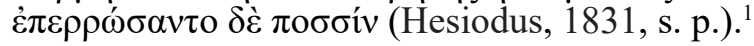

Na primeira linha, ao indicar o motivo de seu ảeídeıv («cantar»), o narrador já dá indícios do loco discursivo de todo o poema: o ciclo teogônico e a natureza desse universo mítico serão iluminados/revelados pela linguagem das musas, as filhas da Memória, desde o dï $\theta$ ’ 'E $\lambda 1 \kappa \tilde{\omega} v o \varsigma$ («Monte Helicon»), um ponto alto, sublime e divino da Grécia Antiga. Esse mesmo timbre encimado e numinoso do conteúdo se conecta à forma da expressão. Constata-se, desde o início, o fato de os versos do fragmento se integrarem formalmente, além de sintática e semanticamente. Isto é, as palavras empregadas se organizam em uma equilibrada alternância de sílabas longas e breves, ao longo de linhas intencionalmente sistematizadas em grupos métricos padronizados, como se vê na

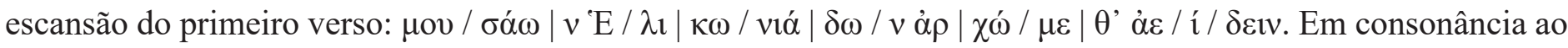
tema representado, tal recorrência rítmica e métrica, denominada de hexâmetro, revela, por meio de uma relação indicial, uma atmosfera «rara» (Aristóteles, 2013, p. 28), aquém «do tom habitual do diálogo» (Aristóteles, 2013, p. 28) e, sobretudo, de altiva seriedade/solenidade.

A correspondência entre os aspectos puramente sensoriais das linhas abordadas e a significação inicial mencionada por Aristóteles (2013) demonstra um processo que exige o entendimento relativo à referencialidade icônica do texto, ao seu desdobramento enquanto signo na primeiridade, secundidade e terceiridade. Na medida em que os aspectos plásticos passam a se enquadrar aos espaço-temporais e se estabelecer propriamente como signos, as imagens se tornam «hipoicônicas e icônicas, já que [...] representam e formam uma estrutura de elementos cromáticos e eidéticos.» (Santaella; Nöth, 2001, p. 151). Desse modo, constrói-se na repetição das formas presentes em todo o poema uma concatenação entre as partes, uma similaridade para além da aparência unívoca. Se tem assim a semelhança na relação: uma iconicidade duplamente imagética e diagramática.

Conforme Torrano (Hesíodo, 1995), após esse proêmio da invocação das musas, inicia-se, em uma estrutura de três ciclos cósmicos, a efabulação das origens e das transformações do universo. A princípio, nesse espaço-

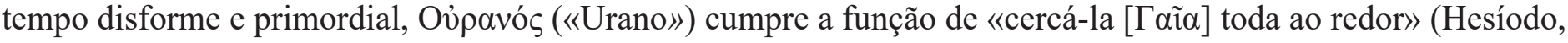
1995, p. 91) e assentar os «deuses venturosos» (Hesíodo, 1995, p. 91) sob si mesmo.

Nos termos de Torrano (Hesíodo, 1995), ao fecundar a Terra e consequentemente originar e sustentar a existência de seus descendentes, Urano funda a temporalidade dessa primeira fase: o reinado hierogâmico do céu, constituído pela pletora engendrada nas torrentes permanentes de vida. No entanto, ao se sentir «ofendida no coração» (Hesíodo, 1995, p. 93), por seu igual ocultar os filhos logo ao nascerem na sua própria «cova» (Hesíodo, 1995, p. 92), a deusa instiga «Crono de curvo pensar» (Hesíodo, 1995, p. 92) a interferir na procriação unívoca que se perfazia. Assim, armado da foice forjada por sua mãe e recôndito, o titã avança sobre o pai e ceifa seu pênis «com ímpeto» (Hesíodo, 1995, p. 92), lançando-o «a esmo para trás» (Hesíodo, 1995, p. 93). De modo que de uma parte dele surgem as Erínias, os Gigantes e as ninfas e de outra Afrodite. Portanto, sob a maldição «de que

\footnotetext{
1. Tradução de Torrano (Hesíodo, 1995, p. 88): «Pelas Musas heliconíades comecemos a cantar. / Elas têm grande e divino o
} monte Hélicon, / em volta da fonte violácea com pés suaves / dançam e do altar do bem forte filho de Crono». 
Algumas comparações entre a Teogonia, de Hesíodo e Saturno Devorando Um Filho, de Francisco de Goya castigo teriam no porvir» (Hesíodo, 1995, p. 94) e da nova forma de amor instituída pela Citereia, estabelece-se o reinado da segunda fase cósmica. Em virtude da sua conduta sinuosa e ardilosa, já vista na atuação contra o pai, Crono submete à Reia — progenitora de filhos, como Héstia, Deméter, Hera, Hades e Zeus — e ingere todos os recém-nascidos, conforme consta do trecho a seguir:

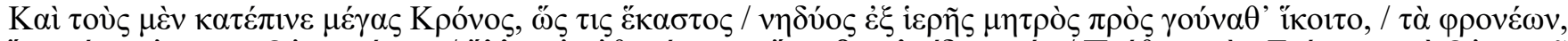

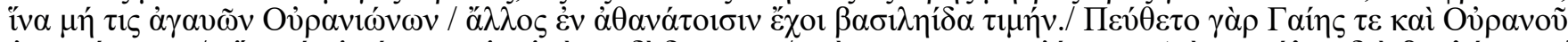

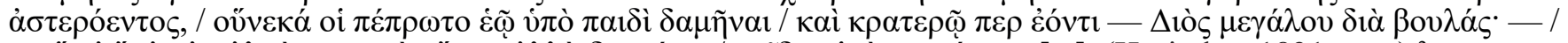

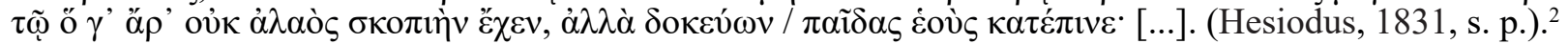

No excerto apresentado, o poeta representa tão somente o essencial: dentro dos limites da composição, tomam lugar o engolimento, os atores principais envolvidos e as razões já enunciadas anteriormente de tal ato. Dito de outra maneira, o narrador da Teogonia ilumina tacitamente as partes fundamentais e oculta as outras - explicitamente, o tempo, o espaço e os filhos são indefinidos — , causando um efeito objetivo em determinados casos e sugestivo em outros. Não obstante, conforme Torrano (Hesíodo, 1995), a ação de vigilante sempre à espreita se torna no enredo contraditoriamente a sua força e o seu limite. Pois, graças a um sortilégio de Reia, Crono é vencido pelas «artes e violência» (Hesíodo, 1995, p. 103) de Zeus e banido para o Tártaro após a Titanomaquia. Conclui-se, assim, o ciclo das três fases cósmicas, a saber: «a união do corte (confronto de Céu e Crono), a união da Guerra (em que o Todo arde em Fogo), e as uniões nupciais de Zeus com diversas Divindades» (Hesíodo, 1995, p. 49), herdeiras das Potestades Originais, Caos, Céu e Oceano.

$\mathrm{Na}$ composição épica, todos os acontecimentos estão intimamente vinculados a si mesmos e à estrutura de um local e de uma época mítica e isolada - as três eras cósmicas. Desse modo, nenhum fragmento pode ser devidamente compreendido fora da totalidade espaço-temporal do poema. De maneira semelhante, o material — os acidentes e as peripécias figuradas — e a sua apresentação - a métrica e o ritmo dos versos no campo diagramático - operam harmoniosamente em um mesmo tom de gravidade, resultado, não do gênio do poeta, mas da materialização de uma antiquíssima junção da tópica e tradição oral sob a forma escrita. Tais aspectos revelam uma problemática ainda mais profunda, a da normatização do gênero épico. Por ser determinado e profundamente envelhecido, fruto das condições de um passado inacessível a ser conhecido por obra e graça de

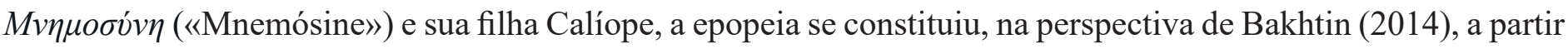
de três traços principais, sumarizados a seguir:

1. O passado nacional épico, «passado absoluto», segundo a terminologia de Goethe e de Schiller, serve como objeto da epopéia; 2. A lenda nacional (e não a experiência pessoal transformada à base da pura invenção) atua como fonte da epopéia; 3. O mundo épico é isolado da contemporaneidade, isto é, do tempo do escritor (do autor e dos seus ouvintes), pela distância épica absoluta (Bakhtin, 2014, p. 405).

O articulador desse discurso poético se dirige ao passado inacessível, infinitamente distante, perdido nos

2. Tradução de Torrano (Hesíodo, 1995, p. 102): «E engolia-os o grande Crono tão logo cada um / do ventre sagrado da mãe descia aos joelhos, / tramando-o para que outro dos magníficos Uranidas / não tivesse entre os imortais a honra de rei. / Pois soube da Terra e do Céu constelado / que lhe era destino por um filho ser submetido / apesar de poderoso, por desígnios do grande Zeus. / E não mantinha vigilância de cego, mas à espreita / engolia os filhos [...]». 
Algumas comparações entre a Teogonia, de Hesíodo e Saturno Devorando Um Filho, de Francisco de Goya tempos primevos, «[...] das “origens" e dos "fastígios" da história nacional, o mundo dos pais e ancestrais, o mundo dos "primeiros" e dos "melhores"» (Bakhtin, 2014, p. 405). Por essa perspectiva, a fonte formal conteudística dela se sustenta na lenda sagrada e peremptória da nação, na sua memória enquanto objeto universal solícito de «uma atitude de reverência para consigo» (Bakhtin, 2014, p. 408). Como resultado, o distanciamento engendrado pelo passado dos primórdios e da memória impessoal produz um mundo perfeito/acabado, «[...] construído numa zona da representação longínqua, absoluta, fora da esfera do possível contato com o presente em devir, que é inacabado e por isso mesmo sujeito a reinterpretação e a reavaliação» (Bakhtin, 2014, p. 409). Ao analisar a Teogonia a partir de tal tratamento artístico, a cena do engolimento dos filhos por Crono se amplia para além da esfera do ícone imagético e diagramático, ou seja, do objeto concebido apenas em virtude de seus caracteres próprios e de seu encadeamento. Por meio das relações triádicas de Peirce (2005), se pode observar nesse desdobramento de sentidos proporcionado pela convencionalização do gênero, condensado no fragmento do engolimento realizado por Crono, a implicação de uma terceira rede de signos. Da progressiva combinação das palavras e sentenças, dos diagramas perceptuais e conceituais, acentua-se a sincronia entre o literal e o simbólico. Forma-se na generalidade épica da Teogonia um paralelo entre o caráter representativo do signo: há o «seu significado, e algo diverso dele» (Santaella, 2001, p. 62). Tal processo de encapsulamento das figurações mais simples pelas mais complexas no interior do ícone é demonstrado no quadro a seguir:

\begin{tabular}{|c|c|c|}
\hline Ícone imagético & Ícone diagramático & Ícone metafórico \\
\hline 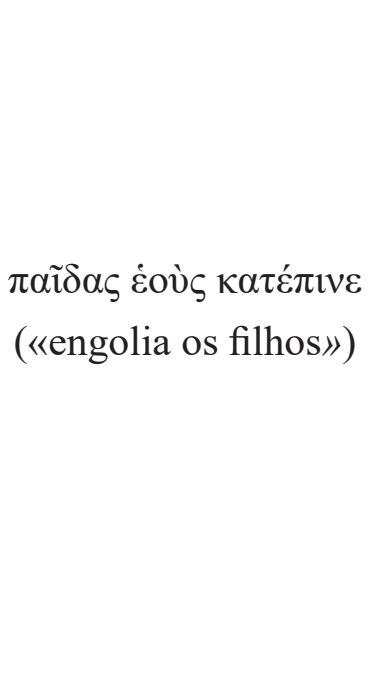 & $\begin{array}{l}\text { Por meio de uma associação } \\
\text { de semelhança estrutural, os } \\
\text { versos hexâmetros ilustram } \\
\text { diagramaticamente o tom } \\
\text { grave do conteúdo. }\end{array}$ & $\begin{array}{l}\text { Como na epopeia, «a estrutura do todo } \\
\text { se repete em cada parte, e cada parte } \\
\text { é acabada e fechada como um todo» } \\
\text { (Bakhtin, 2014, p. 421). O trecho } \\
\text { do engolimento se torna uma etapa } \\
\text { simbólica da concepção de mundo } \\
\text { totalizante, perfeita, peremptória e } \\
\text { inacessível, daquilo que Lukács (1885- } \\
\text { 1971), em A teoria do romance (2009), } \\
\text { identificava como o círculo ocluso em } \\
\text { que viviam metafisicamente os gregos. }\end{array}$ \\
\hline
\end{tabular}

Quadro 1. Rede de significações icônicas na Teogonia

Como se observa, a generalidade do símbolo não está no ícone ou no índice, mas na lei, na convenção ou norma do epos (acontecimento portentoso). Assim, por se integrar ao resto do poema, a peripécia efabulada (o

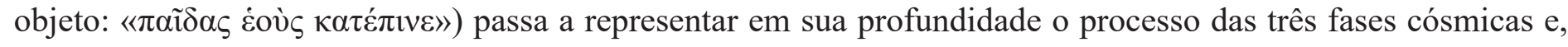
portanto, do mundo mítico, acabado e determinado do gênero épico. 
Algumas comparações entre a Teogonia, de Hesíodo e Saturno Devorando Um Filho, de Francisco de Goya

\section{O mundo alheado de Saturno devorando um filho, de Francisco de Goya: entre o sangue, a loucura e o abismal}

Desde a escritura da Teogonia, foram produzidas diversas releituras da cena para outras formas de expressão de arte, como o artesanato e a pintura. Restritos aos limites dos seus tempos e meios, os artistas conceberam essas traduções de distintos modos, ora buscando reproduzir o cânone hesiódico, ora mudando-o de acordo com os seus interesses. A pintura do vaso ateniense da pedra de Omphalos, do Museu Britânico, e o retrato de Saturno (Crono sincretizado no culto romano), do Museu Arqueológico de Nápoles, são exemplos de releituras clássicas atentas à manutenção da representação épica. Já as obras Saturno devorando um filho (1636-1638), de Peter Paul Rubens, e Saturno em um nicho que devora seu filho (1526), de Giovanni Jacopo Caraglio e são amostras das constantes transformações da figuração desse mito ao longo da história medieval e moderna. Nesse cenário, conforme Todorov (2014), Francisco José Goya y Lucientes, nascido na cidade espanhola de Fuendetodos em 1746, surgiu como fundamental para a arte europeia/ocidental em razão de promover uma renovação da tradição iconográfica estabelecida até então.

A trajetória pictórica de Goya pode ser fragmentada em dois períodos: uma fase inicial, de natureza reprimida, em que Todorov (2014) apontou seus primeiros trabalhos e afrescos como de cunho religioso — pois a maioria de suas encomendas eram relativas à igreja. O elemento lúgubre e inquietante era ocultado pela harmonia, equilíbrio, proporcionalidade e singeleza das formas ditadas pela época. Por conseguinte, se tem as obras Cristo crucificado (Goya, 1780) e La vendimia/El otoño (Goya, 1786), ilustrando o estilo neoclássico em que o pintor se desvirtuava progressivamente.

O segundo período se inicia depois de receber, em 1789, o título máximo como artista da época — Pintor da Câmara do Rei Carlos vi. Goya contraiu uma enfermidade que o deixou surdo. Segundo Mestres de Pintura (1977), a doença alterou sua perspectiva da sociedade, seu modo de enxergar a vida e aguçou o seu senso visual, como se observa nas gravuras e pinturas de Los caprichos ([1799], 1969) e Os Desastres da Guerra ([1810-1815], 1863).

Com a invasão de José Bonaparte à Espanha em 1808 e o posterior retorno de Fernando vII ao trono (17841833), aconteceram uma série de perseguições aos, assim chamados, afrancesados. De acordo com Mestres da Pintura (1977), como muitos dos amigos de Goya foram obrigados a emigrar, o artista ficou sozinho e isolado em uma residência de campo aos arredores de Madri, conhecida por Quinta del Sordo. Nas paredes dessa casa, o pintor registrou quatorze imagens repletas de tons escuros, melancólicos e misteriosos — o que lhes rende posteriormente o título de Pinturas Negras (Goya, 1820-1823). Nesse grupo, acha-se uma das transposições mais controversas do episódio teogônico, abordado anteriormente: Saturno devorando um filho, representada a seguir: 


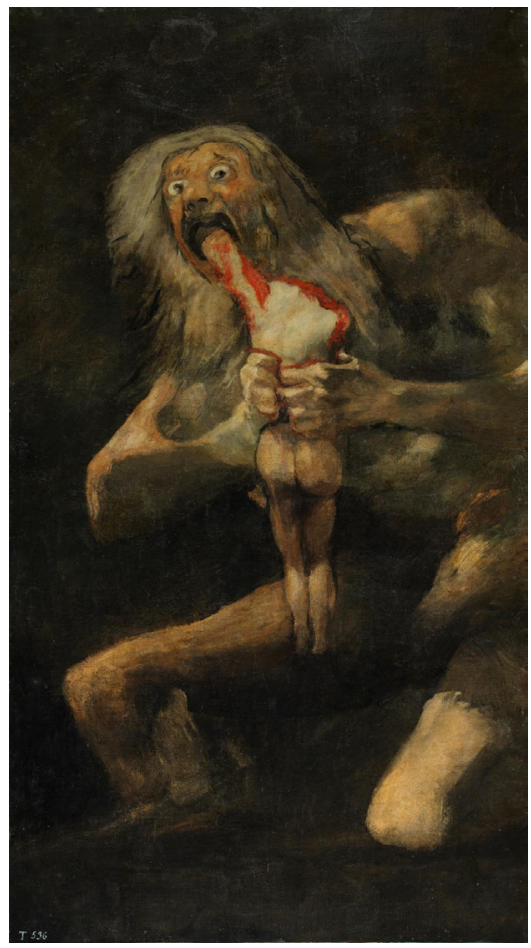

Figura 1. Saturno devorando um filho (1820-1823). Fonte: Museu do Prado, Madri (s. f.).

Ao tomar por referência a visão de quem chegava pela entrada principal do local, o quadro estava ao fundo do térreo, indexado à sala de jantar do pintor. Saturno devorando um filho foi elaborado por meio de uma técnica mista sobre um mural e transladado, posteriormente, para uma tela de 143,5 centímetros de altura por 81,24 centímetros de comprimento. Tal dimensão, que se aproxima de uma proporção retangular de 2:1, encurta a extensão horizontal perceptível ao observador e alonga a medida do sentido vertical. Isso significa que as tensões materializadas na pintura, entendidas por Arnheim (2005) como uma experiência visual dinâmica, equilibram e desequilibram-se, fundamentalmente, de duas formas: de uma maneira dominante, entre a parte alta e a baixa, onde se concentra a ação da cena; de uma maneira retroativa, entre o campo do visível e do não visível das laterais. Esse arranjo, portanto, dá indícios de uma composição espacialmente carregada de inquietude e energia.

Assim, ao reorganizar os ícones da tradição hesiódica, por meio de uma linguagem não-verbal, Goya (18201823) criou, nesse ambiente dinâmico e verticalizado, uma relação entre o fundo, Crono (Personagem 1), e o suposto filho (Personagem 2). A base se apresenta como um plano misterioso, caracterizado pelo negro profundo e o desconhecido. O uranida, posto nu nessa treva sorvedora e baixa, é pintado opressivamente maior do que o outro e compõe mais de um terço do lócus, mesmo inclinado em um ângulo de aproximadamente 45 graus. Com as costas cravejadas pelas mãos do titã, o último, imóvel e também despido, apresenta o lado direito do corpo e a cabeça decepados, enquanto o braço esquerdo é devorado exatamente no momento da elaboração do cenário.

A partir de um olhar mais atento acerca da estruturação das duas personagens e dos seus vínculos espaciais, se constata, com base nos conceitos revisados por Arnheim (2005), a utilização de três técnicas de profundidade 
Algumas comparações entre a Teogonia, de Hesíodo e Saturno Devorando Um Filho, de Francisco de Goya fabricadas artificialmente nessa transposição de caráter bidimensional. O artista lançou mão da perspectiva na relação estabelecida entre o tronco e a parte inferior do corpo de Crono; da superposição no posicionamento deste último sobre o fundo e do claro-escuro, também chamado de isométrico, em determinadas partes dos membros de ambos os entes. Pelo conhecimento do emprego de tais técnicas, se chega a uma subdivisão de cinco planos decrescentes, a saber: i) a perna inferior esquerda da Personagem 1, com a região do joelho mais clara e alta; ii) próximo ao centro da imagem, as mãos do corpo maior; iii) em seguida, o corpo da personagem menor; iv) mais atrás, a cabeça da Personagem 1 fixada no segundo quarto da parte superior esquerda, o tronco e perna esquerda; v) o fundo escuro e neutro. Esse relevo contínuo, no qual áreas e distâncias diferentes se limitam umas com as outras, engendra uma pseudo tridimensionalidade capaz de representar em várias camadas a posição descompassada das personagens e suas ações.

Ademais, o jogo de contrastes, especialmente entre as luzes e as sombras dessas regiões limitantes, é um traço distintivo do modus operandi do pintor, como confirmou Arnheim (2005, p. 294): «Alguns artistas como Rembrandt ou Goya, pelo menos alguma vez, mostram o mundo como um lugar intrinsecamente escuro, iluminado aqui e ali pela luz». Isto é, ao menos nessa tradução, se contempla um jogo de oposições entre a ausência e a presença da luz. Por um lado, há a escuridão quase absoluta, considerada a encarnação das coisas além dos sentidos, detentoras de um poder sobre os espectadores; por outro, pontos de sombras próprios e não, que servem «[...] simplesmente para definir volume» (Arnheim, 2005, p. 304) e modalizar o ambiente, ou de gradientes claros que emanam, notoriamente, do rosto e da coxa esquerda do titã, bem como das costas e das nádegas da Personagem 2.

Logo, além do destaque dado pela disposição das camadas ser reforçado por meio do uso das luzes e das sombras, a maneira pela qual Goya (1820-1823) incorporou os elementos de luminescência e escuridão em seu labor produziu uma deformação/desvanecimento de certas porções dos ícones imagéticos e um realce de outras, como decorre na exposição do engolimento na Teogonia, em que poucos detalhes são dados ao leitor, porém agora em uma condição transfigurada e visualmente inacabada.

O mesmo se reflete na aplicação das cores: predominam, nessa pintura com uma paleta extremamente limitada, matizes de saturação e de neutralidade cromática. Assim, em Crono, há tons escuros, o tronco, o antebraço esquerdo, a coxa direita e a parte interior da coxa esquerda, e tons claros, como o cabelo, o olho, as mãos e a região do joelho direito. Na outra, se verifica o tom claro das costas. Constata-se ainda cores quentes: no titã, partes de ocre amarelo e vermelho do rosto, ombro direito, braço direito, esquerdo e parte superior da coxa esquerda, e, no filho, se tem ocre amarelo e vermelho na região das nádegas, com acréscimo do vermelho nos ombros, braço esquerdo e cabeça. Tais escolhas de Goya (1820-1823) amarram-se às sensações de vivacidade e palidez, ou seja, de vida e de morte entre o devorador (Crono) e o devorado (filho). Ao pintar desse modo, ele propôs uma leitura modificada da Teogonia, criando, em outras palavras, uma imagética bárbara e chocante.

Apesar de o caminho do olhar do espectador não necessariamente aderir aos eixos vetoriais engendrados pela composição, para se entender os vários temas dominantes e subordinados da obra, a percepção dos movimentos e dos acontecimentos — entendidos como a ação por meio dos objetos — é essencial para a organização dessa 
Algumas comparações entre a Teogonia, de Hesíodo e Saturno Devorando Um Filho, de Francisco de Goya pintura-narrativa e da própria sequência temporal. Ao centro do quadro, observamos o movimento de esmagamento das mãos do pai sobre as espáduas do filho, que padece, aparentemente, sem vida, enquanto o sangue escorre de suas feridas. Ao seguir a ação, se avista o braço esquerdo da personagem menor sendo engolido/devorado pelo abocanhar da outra. Em um processo sugestivo, se pode entrever seu salivar e vislumbrar o arregalar de olhos do mastigador, bem como o envergamento da musculatura de suas pernas e braços.

Todos esses elementos integrados na seleção de cores, perspectivas e temáticas da pintura confluem para a constituição de uma releitura iconicamente divergente à Teogonia. Ou seja, além de manipular a regularidade configuracional daquele texto através de uma semiose monstruosa e amorfa de quase todos os aspectos formais, Goya (1820-1823) criu um enredo em que, por exemplo, «[...] o ser que ele [Saturno] consome não é nem uma criança nem um homem: tem o corpo de uma jovem» (Todorov, 2014, p. 207) dilacerada violentamente. Além de tais não similitudes no tratamento aparentemente superficial da tela, determinados vestígios indicam ou sinalizam uma segunda rede de significações.

O sangue - fundamental no campo imagético da tradução por sua centralidade longitudinal/latitudinal, proximidade ao observador nas camadas de profundidade, tonalidade e saturação (atributos pertencentes à primeiridade do ícone) — relaciona-se, ainda, a um segundo componente. Além de não existir na narrativa de Hesíodo (1995), esse objeto se estabelece como um indício da devoração desumana e caliginosa de Crono: se tem aí uma combinação diagramática de ícones. Em razão de sua própria natureza biológica, tal associação analógica do sangue com a violência pode ser esquadrinhada no interior das medidas constituintes do conceito de corpo grotesco de Bakhtin (2010), definido a seguir:

Os principais acontecimentos que afetam o corpo grotesco, os atos do drama corporal - o comer, o beber, as necessidades naturais [...], a cópula, [...] a velhice, as doenças, a morte, a mutilação, o desmembramento, a absorção por outro corpo - efetuam-se nos limites do corpo e do mundo ou nas do corpo antigo e do novo; em todos esses acontecimentos do drama corporal, o começo e o fim da vida são indissoluvelmente imbricados. (Bakhtin, 2010, p. 277, grifos dos autores).

Ao enumerar uma série de degradações do âmbito fisiológico, o crítico precisa o drama corporal como aquilo «[...] tudo que sai, procura sair, ultrapassa o corpo, tudo o que procura escapar-lhe» (Bakhtin, 2010, p. 276). Por conseguinte, o sangramento e a agressividade do desmembramento performam por uma parecença nas relações com o corpo grotesco nessa primeira instância indicial. Outro tópico citado é a absorção: aqui, a ingestão do filho pelo pai toma um lugar importante, notoriamente, na formatação dos olhos arregalados e da boca escancarada. Em um encaminhamento similar ao do conteúdo, a produção dos ícones da face, ou seja, dos olhos e da boca, esse «abismo corporal escancarado e devorador» (Bakhtin, 2010, p. 277), opera como diagrama/índice da loucura, do distúrbio, da insânia. A respeito da efabulação do traço humano a partir de um tom desvairado, Kayser (1986) enunciou:

Na demência, o elemento humano aparece transformado em algo sinistro; mais uma vez é como se um id, um espírito estranho, inumano, se houvesse introduzido na alma. O encontro com a loucura é como uma das percepções primigênias do grotesco que a vida nos impinge [...] o mundo grotesco causava a impressão de ser a imagem do mundo vista pela loucura. (Kayser, 1986, p. 159). 
Algumas comparações entre a Teogonia, de Hesíodo e Saturno Devorando Um Filho, de Francisco de Goya

Conforme declarou o autor, a interferência do delírio metamorfoseia o ser humano em um ente assustador, como se o sujeito pensasse em função de um desejo inconsciente, simultaneamente novo e habitual, estranho e reconhecível - expresso, como no id de Sigmund Freud (2010), dos atos falhos, chistes, lapsos. Nessa lógica, ao se pensar, como Santaella (2001), que a categoria da secundidade não é somente uma relação com o objeto, mas com o representante e o interpretamen, conclui-se que a constituição icônica do rosto do assassino passa a figurar dentro de uma ordem diagramática, simultaneamente narrativa e cultural, esse campo usado na modernidade: do estranho, concomitantemente desconhecido e familiar.

Tendo em vista tais apontamentos, se observa nessa releitura das imagens e diagramas feitos por Goya (18201823) um tipo de estranhamento, inquietação ou desconforto distinto daquela existente na Teogonia. Nessa visada, o autor ressignificou o mito teogônico. Em uma primeira instância, as duas imagens colocadas sobre um fundo escuro poderiam ressonar como a representação da brutalidade, da loucura e do canibalismo revelado pelo sangue brilhante, a face contorcida, os olhos arregalados, a boca escancarada, e a própria monstruosidade do ato eternizado pela tela. Somando-se a isso, em uma segunda instância, a deformidade dos objetos, causada pela ausência de linhas marcantes e a fuga da perfeição estética clássica realista, a escuridão profunda, contrastada com a desarmonia dos dois corpos, e o desequilíbrio das proporções poderiam dar a entender como uma arte de tom caricatural.

Santaella (2001) indicou como tal disposição oferece um paralelo entre o caráter alusivo do signo (seu significado) e algo diverso dele. O diferente se forma precisamente como qualidade do ícone metafórico do grotesco, isto é, daqueles «signos que representam o caráter representativo de um representamen [signo] por representarem um paralelismo com algo mais» (Peirce, 1992, como se citou em Santaella, 2009, p. 304). Por meio do Quadro a seguir, se pode perceber, nas relações triádicas de Peirce (2005), os fatores empregues em tal perfazer grotesco:

\begin{tabular}{|c|c|}
\hline \multirow{6}{*}{ Ícones imagéticos } & $\begin{array}{l}\text { Configuração: conexão do fundo, Crono (Personagem 1) e o suposto filho } \\
\text { (Personagem 2). }\end{array}$ \\
\hline & Equilíbrio: tensão entre a vertical e horizontal. \\
\hline & Espaço: disposição inflada de inquietude e energia. \\
\hline & Luz: jogo de oposições entre as luzes e as sombras. \\
\hline & $\begin{array}{l}\text { Cor: efeitos de vivacidade e palidez, isto é, de vida e de morte entre o devorador } \\
\text { (Crono) e o devorado (filho). }\end{array}$ \\
\hline & $\begin{array}{l}\text { Movimento: esmagamento das espáduas do filho pelas mãos de Crono, Braço } \\
\text { esquerdo da figura menor sendo mastigado. Salivar e vislumbrar o arregalar de } \\
\text { olhos do devorador, bem como o curvar da figura maior e a rigidez da musculatura } \\
\text { de suas pernas e braços. }\end{array}$ \\
\hline
\end{tabular}




\begin{tabular}{|c|l|}
\hline \multirow{1}{*}{ Ícones diagramáticos } & $\begin{array}{l}\text { Sangue/morte: De acordo com o dicionário Bueno (2000, p. 698), o sangue } \\
\text { pode ser delineado como «a vida; prole; geração; natureza; família». Verificada a } \\
\text { cena brutal de parricídio/canibalismo/desmembramento, com o verter de sangue } \\
\text { da figura 2, na obra de Goya (1820-1823), o derramamento de sangue, entendido } \\
\text { como a causa imprescindível da existência, relaciona-se à morte. }\end{array}$ \\
\cline { 2 - 3 } & $\begin{array}{l}\text { Olhar/boca/demência: o pintor figurou, o corpo delgado de um homem com } \\
\text { olhar sedento e arregalado, de tensão puramente corporal direcionado ao } \\
\text { observador. A boca, completamente aberta, domina, é ostensiva e escancarada, } \\
\text { esforçando-se para devoração do membro. Desse modo, através da face, pavorosa } \\
\text { ou hedionda, Goya (1820-1823) ressignifica o mito, concebendo Crono como } \\
\text { uma personagem desprovida de juízo, a quem sofre de insanidade. }\end{array}$ \\
\hline Ícones metafóricos & $\begin{array}{l}\text { Grotesco: Com a soma dos elementos anteriores, seus aspectos de forma } \\
\text { e conteúdo, a pintura, Saturno devorando um filho, de Francisco de Goya, é } \\
\text { ressignificada em uma arte aterradora. Afastando-se da epopeia - que é perfeita } \\
\text { e bem acabada em seu aspecto profundo - e aproximando-se de um mundo } \\
\text { disforme, obscuro, heteróclito, inacabado e imperfeito, a obra pode ser mais bem } \\
\text { definida por sua representação semiótica do grotesco. }\end{array}$ \\
\hline
\end{tabular}

Quadro 2. Rede de significações icônicas em Saturno devorando um filho

Em um aprofundamento da natureza sígnica, a pintura se congrega, no domínio da terceiridade, ao grotesco, caracterizado, conforme Kayser (1986), por se manifestar, dentre outros modos, como uma estrutura ou um sistema em que o mundo é transfigurado em algo estranho. Com efeito, aquilo que era conhecido e familiar em Teogonia se torna, na representação de Goya (1820-1823), um conjunto de significações desconhecidas e reprimidas. Uma angústia distintiva é gerada no indivíduo: a inquietude da vida, pois, através dos elementos icônicos utilizados pelo artista, a pintura pode se estabelecer na recepção como um artefato carregado de tensão e violência, motivo de repulsa e espanto.

De acordo com Kayser (1986), tal percepção de mundo alheado surge, em uma primeira instância, da falha humana em conceber a hibridização das categorias, como se observa com «[a] mistura dos domínios para nós separados, a abolição estática, a perda da identidade, a distorção das proporções "naturais" e assim por diante» (Kayser, 1986, p. 159). Ao fim, o observador se depara no abismal com «a suspensão da categoria de coisa, a destruição do conceito de personalidade, o aniquilamento da ordem histórica» (Kayser, 1986, p. 159).

O efeito produzido na transformação de um tipo ideal por meio da exageração de um de seus elementos ou da combinação com os outros também é explorado por George Santayana, em The Sense of Beauty (1955), porém de uma visada estética. Na argumentação do autor, a idiossincrasia do grotesco irrompe da configuração de algo não presente na natureza, mas passível de ser. Similar à condição da arte em Aristóteles (2013), tal categoria estética 
Algumas comparações entre a Teogonia, de Hesíodo e Saturno Devorando Um Filho, de Francisco de Goya consiste, então, em uma recriação do possível. Ao se imprimir na imaginação do receptor, de modo que ele ainda reconheça naquela confusão ou estranheza um senso de caracterização, proporção e unidade, a forma intrínseca do grotesco se mostra latente. Em resumo, a sua percepção se dá com «the half-formed, the perplexed and the suggestively monstrous.» (Santayana, 1955, p. 157).

Contudo, ao se aproximar mais da probabilidade interna do que da natureza, Santayana (1955) sugeriu uma desarticulação do grotesco no âmbito do observador. Com a análise e o entendimento de sua condição particular, a incongruidade previamente convencionada desaparece e o estranho retorna ao ideal e aceitável. Em um intuito comparativo, o pensador associu a impressão do grotesco à experiência individual. Nas palavras de Santayana (1955), assim como a opinião de um sujeito sobre o outro é suscetível de mudança, na medida em que ele é capaz de discernir, na harmonia interior do outro, o equilíbrio de seus traços interiores, as características da feiura e do repulsivo, outrora relacionadas a um determinado conjunto de signos, também podem desaparecer ou se ocultar na experiência estética de uma pintura, por exemplo.

Em uma aproximação da oscilação entre o aceitável e o inaceitável, o conhecido e o desconhecido de Santayana (1955), foram utilizados os estudos empreendidos por Sigmund Freud em O inquietante (2010). O texto do psicanalista inicia com a declaração de que os tratados de estética se ocuparam, sobretudo, «das belas, sublimes e das atraentes sensibilidades» (Freud, 2010, p. 330). Desse modo, eles se ausentaram daquilo que poderia ser considerado repugnante e provocaram uma certa dificuldade na compreensão dessa modalidade. Em seguida, ele projetou a sua tentativa de delineamento do conceito. Para chegar nessa ideia, que não é uma definição ontológica absoluta e estabilizada, o psicanalista partiu para a revisão etimológica do vocábulo.

Ao pensar sobre a palavra alemã unheimlich, Freud (2010) apresentou, preservando uma literalidade, o prefixo negativo un e heimlich, oriundo de heim, que significa «lar». Portanto, o termo unheimlich seria traduzido como o «não familiar». O autor ampliu sua rede de significação para as traduções de alguns idiomas, a fim de demonstrar uma variedade de expressões para a negação do familiar. O latim faz alusão a um local, equivalente de unheimlich, seria locus suspectus («lugar suspeito»). No inglês, correspondente ao desconfortável, inquieto, sombrio, estranho, sinistro, medonho, lúgubre e grotesco. No espanhol, há o suspeito, de mau presságio, sinistro, inquietante. Por fim, em hebraico e árabe, demoníaco e ameaçador.

Não obstante, ele continuou a tratar da essência do inquietante ao enumerar as ocorrências que se perfazem nele, como o animismo, a magia, a feitiçaria, o complexo da castração, o narcisismo infantil, a repetição, entre outros. Dos fatores listados por Freud (2010), em um esquema balizado pelos polos da confiança, do oculto e do animado em contrariedade à distância, ao público e ao morto, assoma-se um exame minucioso acerca do contato entre a morte e «o sentimento inquietante produzido [...] pelas manifestações de loucura». (Freud, 2010, p. 340). Na explicação do pensador, a impressão do «infamiliar» nasce, no caso desses dois temas, em razão da atribuição de más intenções a certos entes. Nesse sentido, é fundamental que esses influxos degradantes se realizem, seja na vida ou na ficção, acompanhados de «forças especiais» (Freud, 2010, p. 362) e secretas. Irmanam-se, portanto,

\footnotetext{
3. Tradução livre dos autores: «o incompleto, o perplexo e o sugestivamente monstruoso.»
} 
Algumas comparações entre a Teogonia, de Hesíodo e Saturno Devorando Um Filho, de Francisco de Goya do demoníaco, na acepção dos versos de Jardim de Marta (Goethe, 2011) citados pelo psicanalista, em que Mefistófeles fala de Gretchen: «Sim, e a fisionomia, isso é com ela! / Ao ver-me fica com aflição, / Meu rosto senso oculto augura; / Sente que um gênio sou, se não / O próprio diabo porventura.» (Goethe, 2011, p. 301).

Na composição pertencente à matriz pictórica, há, pois, uma faceta diabólica/mefistofélica dos eventos da morte e da loucura. O ícone imagético, concebido pelas particularidades formais da pintura, apresenta as técnicas utilizadas pelo pintor para pincelar a tensão inerente à obra. Os ícones diagramáticos se coligam à insanidade estampada no rosto de Crono e à violência, nitidamente verificada pelo derramamento de sangue do filho. Por fim, o ícone metafórico, resultado da semiose do grotesco, em que a cena de canibalismo explícito traduz da literatura este acontecimento, presente no mundo inteligível, realiza-o no mundo sensível. Embora Freud (2010) tenha se aprisionado em um círculo hermenêutico nas primeiras partes do ensaio, foi obtida uma valiosa amostra de sentidos que remetem a uma descrição congênere a de Saturno devorando um filho. Enunciado de outra maneira, na perspectiva introdutória dos vocábulos, a pintura se associa à estranheza e fonte de inquietação.

Ademais, em determinadas efabulações artísticas «não é inquietante muita coisa que o seria na vida real, é que nela existem, para obter efeitos inquietantes, muitas possibilidades que não se acham na vida.» (Freud, 2010, p. 371), de modo que «o escritor pode exercer e multiplicar o inquietante muito além do que é possível nas vivências, ao fazer sobrevir acontecimentos que jamais — ou muito raramente - encontramos na realidade. » (Freud, 2010, p. 373). A respeito dessa capacidade manifesta na literatura e na pintura, o crítico já havia versado em Os Dois Princípios do Suceder Psíquico (Freud, 1997).

$\mathrm{Na}$ argumentação do psicanalista, perante a insatisfação das vontades exigidas pelas pulsões, surge eventualmente o abandono da tentativa de alcançá-las. Em Freud (1997), esse conflito levaria às alucinações ou às representações das circunstâncias reais do mundo exterior como um modo de tender em direção à conquista do supostamente real. Em tal conjuntura, como se observa na lógica do ensaio citado, a arte conseguiria conciliar as pulsões humanas em uma profusão criativa dos desejos. Por essa visada, o artista seria capaz de, por suas próprias vias e em alguma medida, restituir as forças reprimidas no mundo material. Logo, poder-se-ia alegoricamente identificar no engolimento a figuração dos horrores da guerra napoleônica, a tirania régia ou o tempo (Crono) que impetuosa e inexoravelmente devora o homem (filha/filho).

\section{Considerações finais}

Ao analisar-se, neste artigo, a transposição realizada na pintura de Goya (1820-1823) a partir de sua correspondência com o poema da Antiguidade, se reconhecem uma série de diferenças entre ambos os textos. Essa polissemia demonstra que não há um liame de fidelidade absoluta entre o objeto literário modelo e a tradução. Baseando-se diretamente nele ou não, o pintor, ao trabalhar com uma linguagem de outra natureza, possibilitou a confluência de velhas e novas formas semióticas, tanto imagéticas e diagramáticas, quanto metafóricas. Nesse segmento, os signos manejados na tradução se aproximaram de «novos objetos imediatos, novos sentidos e novas 
Algumas comparações entre a Teogonia, de Hesíodo e Saturno Devorando Um Filho, de Francisco de Goya estruturas que, pela sua própria característica diferencial, tendem a se desvincular do original» (Plaza, 2013, p. 30). Logo, a tradução intersemiótica estética instiga a descoberta de realidades outras, na medida em que o segundo signo traduz o primeiro não para reproduzi-lo, «mas para reverberá-lo, para criar com ele uma ressonância» (Plaza, 2013, p. 27). Funda-se nesse eco intersemiótico uma iluminação recíproca das artes: segundo Peirce (2005), apesar de o corpo dos símbolos mudar lentamente, seu significado expande inevitavelmente e incorpora novos elementos, livrando-se dos antigos. Assim, na medida em que todo texto se elabora na «absorção e transformação de outro texto» (Kristeva, 1969, como se citou em Carvalhal, 1986, p. 50), tanto Saturno devorando um filho quanto a Teogonia retornam diferentes desse processo.

$\mathrm{Na}$ matriz verbal, se abordaram as três fases da Teogonia a fim de depreender-se a sua composição formal e estrutural. A partir desses dois fatores, foi exposta a base constitutiva da cena do engolimento dos deuses olimpianos pelo seu próprio pai: a representação de um mundo formado pelo passado absoluto, a lenda nacional e o isolamento épico. Com suporte nessas ideias, foram identificadas no trecho uma rede de significações aquém das relações sensoriais e indiciais e foi encontrada a simbolização de um mundo conhecedor de uma única concepção de vida e mundo inteiramente concluído, obrigatório e indubitável para as personagens, o autor e os leitores.

Por sua vez, na matriz pictórica, foram apontados os procedimentos artísticos empregados por Goya (18201823) - como a utilização do equilíbrio, do espaço, da profundidade, da luz, da sombra, da cor, do movimento e da expressão - para transpor em sua obra denominada Saturno devorando um filho o episódio da Teogonia. Com o levantamento de tais elementos, se reconheceu a utilização de ícones desproporcionais e caliginosos, associações à demência e morte e por consequência a simbologia de um mundo apresentado como alheado, tornado estranho e grotesco.

As semelhanças — expressas na base fabular e temática, compartilhada por ambas — e diferenças — manifestadas nas diferentes noções icônicas, indiciais e simbólicas - figuradas entre a Teogonia e Saturno devorando um filho condensam, de um lado, o universo perfeito, acabado da Antiguidade e, de outro, o mundo inacabado, alheado da modernidade. Se verificou, por intermédio da análise do processo de tradução intersemiótica plasmado pelo pintor espanhol, que obras literárias, como Teogonia, podem ser revisitadas no decorrer da história e ressignificadas de maneiras distintas. Assim, ao considerar-se a Arte como um processo de comunicação tal como propôs Arnheim (2005) — em que se realizam diálogos tanto no campo estético, quanto artístico —, se pode afirmar que a tela redimensiona o poema, na medida em que amplia, e complementa os signos explorados pelo poema épico de Hesíodo (1995).

A correspondência da tradução entre a Literatura e as Artes Visuais abarca um movimento criativo capaz de ir da paráfrase ao engenho plurissignificativo, de acordo com a matriz de linguagem, finalidade e habilidades do tradutor. Ao se considerar essa relação intertextual, a tradução intersemiótica proporciona a expansão de novos sentidos em relação ao que já foi feito na obra modelo.

Portanto, analisar quais são os sentidos gerados a partir da tradução intersemiótica de Francisco de Goya (18201823 ) significa demonstrar que o pintor age na interpretação dos signos verbais por meio de signos do sistema não- 
Algumas comparações entre a Teogonia, de Hesíodo e Saturno Devorando Um Filho, de Francisco de Goya verbal, acrescentando elementos de seu próprio universo e, nesse processo, expandindo as qualidades e os sentidos, tanto do poema quanto da obra de matriz visual. A análise de transposições interartísticas permite a identificação de similaridades e diferenças narrativas que simbolizam amplitudes ou distanciamentos intersemióticos; é nessa perspectiva que, segundo Pezzini (2019), pode-se afirmar a coexistência e a transversalidade de obras que se alimentam retroativamente. 
Algumas comparações entre a Teogonia, de Hesíodo e Saturno Devorando Um Filho, de Francisco de Goya

\section{Referências bibliográficas}

1. Aristóteles. (2013). Poética e Tópicos I, II, III, IV. São Paulo: Hunter Books.

2. Arnheim. (2005). Arte e Percepção Visual: Uma Psicologia da Versão Criadora. São Paulo: Martins Fontes. E-book.

3. Auerbach, E. (2015). Mimesis: A Representação Da Realidade na Literatura Ocidental. São Paulo: Perspectiva.

4. Bakhtin, M. (2010). A Cultura Popular na Idade Média e no Renascimento: O Contexto de François Rabelais. São Paulo: Hucitec Editora.

5. Bakhtin, M. (2014). Questões de Literatura e Estética: A Teoria do Romance. São Paulo: Hucitec Editora.

6. Bueno, S. (2000). Minidicionário da Língua Portuguesa. São Paulo: FTD.

7. Calvino, I. (1993). Por qué leer los clásicos. Barcelona: Tusquets.

8. Caragli, G. J. Saturn in a niche devouring his son, standing before a scythe, from a series of mythological gods and goddesses. [Gravura]. Nova Iórque: Metropolitan Museum of Art. https://www.metmuseum.org/art/ collection/search/368120

9. Carlson, M. (1997). Teorias do Teatro. São Paulo: Editora UNESP.

10. Carvalhal, T. F. (1986). Literatura Comparada. São Paulo: Editora Ática.

11. Freud, S. (1997). Los dos princípios del suceder psíquico. En Freud, S. (1997). Los textos fundamentales. Barcelona: Litografia Rosés.

12. Freud, S. (2010). História de Uma Neurose Infantil. São Paulo: Companhia das Letras.

13. Goethe, J. W. (2011). Jardim de Marta. En Goethe, J. W. (2011). Fausto, I. São Paulo: Editora 34.

14. Goya, F. (1780). Cristo crucificado. [Óleo sobre tela]. Madri: Museu Nacional do Prado. https://www. museodelprado.es/coleccion/obra-de-arte/cristo-crucificado/093cbda0-b9c4-445e-b6d3-56c423811 f46

15. Goya, F. (1786). El otoño. [Óleo sobre tela]. Madri: Museu Nacional do Prado. https://www.museodelprado. es/coleccion/obra-de-arte/la-vendimia-o-el-otoo/3fdc2d25-e302-42ec-9ac5-6216ca7bfe74

16. Goya, F. (1820-1823). Saturno devorando um filho. [Óleo sobre reboco trasladado a tela]. Madri: Museu Nacional do Prado. https:/www.museodelprado.es/coleccion/obra-de-arte/saturno/18110a75-b0e7-430c-bc732a4d55893bd6

17. Goya, F. ([1810-1815], 1863). Los desastres de la guerra. Madrid: Publícala Real Academia de Nobles Artes de San Fernando.

18. Goya, F. ([1799], 1969). Los Caprichos. New York: Dover Publications.

19. Hesíodo. (1995). Teogonia: A Origem dos Deuses. São Paulo: Iluminuras.

20. Hesiodus. (1831). Hesiodi carmina. Gothar et Erfordiae. Sumtibus Hennings.

21. Homero. (2003). Odisseia (Tradução de Frederico Lourenço). Lisboa: Cotovia.

22. Homero. (2005). Ilíada (Tradução de Frederico Lourenço). Lisboa: Cotovia.

23. Kayser, W. (1986). O Grotesco. São Paulo: Perspectiva. 
Algumas comparações entre a Teogonia, de Hesíodo e Saturno Devorando Um Filho, de Francisco de Goya 24. Lukács, G. (2009). A Teoria do Romance. São Paulo: Duas Cidades; Editora 34.

25. Macey S. (1978) The Changing Iconography of Father Time. In J. T. Fraser, N. Lawrence, \& D. A. Park, (Eds.) The Study of Time, III. Springer, New York, NY. https://doi.org/10.1007/978-1-4612-6287-9_24

26. Mestres da Pintura. (1977). Mestres da pintura: Goya. São Paulo: Abril Cultural.

27. Peirce, C. S. (2005) Semiótica, 46. São Paulo: Perspectiva.

28. Pezzini, P. G. (2019). Da narrativa literária à cinematográfica: a função estética do PERCOR na tradução intersemiótica de a grande arte e high art (Graduada. Trabalho de Conclusão de Curso). Universidade Estadual do Oeste do Paraná.

29. Plaza, J. (2013). Tradução Intersemiótica. São Paulo: Perspectiva.

30. Rubens, P. P. (1636-1638). Saturno devorando a un hijo. [Óleo sobre tela]. Madri: Museu Nacional do Prado. https://www.museodelprado.es/coleccion/obra-de-arte/saturno-devorando-a-un-hijo/d022fed3-6069-4786-b59f4399a2d74e50

31. Santaella, L. (2009). Matrizes da Linguagem e do Pensamento: Sonora, Visual, Verbal. São Paulo: Iluminuras. 32. Santaella, L. (2001). Imagem: Cognição, Semiótica, Mídia. São Paulo: Iluminuras.

33. Santayana, G. (1955). The Sense of Beauty: Being the Outline of Aesthetic Theory. New York: Dover Publications.

34. Saturno. [s. d.]. Madrid: Museu Nacional del Prado. https://www.museodelprado.es/coleccion/obra-de-arte/ saturno/18110a75-b0e7-430c-bc73 2a4d55893bd6?searchMeta=saturn

35. Todorov, T. (2014). Goya a Sombra das Luzes. São Paulo: Companhia das Letras.

36. Torrano, J. A. A. (1995). Três Ases e Três Linhagens. Teogonia: A Origem dos Deuses (pp. 40-56). São Paulo: Iluminuras.

37. Vico, G. (2015). Ciência Nova. São Paulo: HUCITEC Editora. 